\title{
Kandungan dan Kualitas Nutrisi Limbah Sawit Fermentasi dengan Lentinus edodes
}

\section{Nutrient Content and Quality of Palm Oil Waste Fermented with Lentinus edodes}

\author{
F. Maulana ${ }^{1 *}$, Nuraini ${ }^{2}$, dan Mirzah ${ }^{2}$ \\ ${ }^{1}$ Program Pascasarjana Ilmu Peternakan, Universitas Andalas, Padang - Indonesia \\ ${ }^{2}$ Fakultas Peternakan, Universitas Andalas, Padang - Indonesia \\ *Corresponding E-mail: fajrimaulana.spt@gmail.com \\ (Diterima: 2 November 2020; Disetujui: 29 April 2021)
}

\begin{abstract}
ABSTRAK
Penelitian ini dilaksanakan untuk mengetahui bagaimana pengaruh komposisi substrat yang berbeda pada limbah sawit yang difermentasi dengan menggunakan Lentinus edodes terhadap kandungan protein kasar, kandungan serat kasar, retensi nitrogen dan kecernaan serat kasar. Metode yang digunakan pada penelitian ini adalah metode eksperimen rancangan acak lengkap (RAL) dengan 5 perlakuan yaitu: perlakuan A (100\% limbah sawit), perlakuan B (90\% limbah sawit $+10 \%$ dedak padi), perlakuan C $(80 \%$ limbah sawit $+20 \%$ dedak padi), perlakuan D (90\% limbah sawit $+10 \%$ ampas tahu) dan perlakuan E (80\% limbah sawit $+20 \%$ ampas tahu) dengan 4 ulangan. Ternak percobaan yang digunakan untuk pengukuran kualitas nutrisi terutama retensi nitrogen dan kecernaan serat kasar adalah ayam broiler CP 707 umur 6 minggu (berat badan 1.500 g/ekor) sebanyak 24 ekor. Peubah yang diamati adalah kandungan protein kasar, kandungan serat kasar, retensi nitrogen dan kecernaan serat kasar. Hasil penelitian ini menunjukan bahwa komposisi substrat yang berbeda memberikan pengaruh berbeda sangat nyata $(\mathrm{P}<0,01)$ terhadap kandungan protein kasar, kandungan serat kasar, retensi nitrogen dan kecernaan serat kasar. Dari hasil penelitian ini disimpulkan bahwa 90\% limbah sawit $+10 \%$ ampas tahu merupakan perlakuan optimal (efisien) dengan kandungan protein kasar 22,77\% (\%BK), kandungan serat kasar 14,03 (\%BK), retensi nitrogen 55,09 (\%BK), dan retensi nitrogen 54,02 (\%BK).
\end{abstract}

Kata kunci: limbah sawit, Lentinus edodes, protein kasar, serat kasar, retensi nitrogen, kecernaan serat kasar

\section{ABSTRACT}

This research was conducted to determine the effect of different substrate compositions on palm oil waste fermented using Lentinus edodes on crude protein content, crude fiber, nitrogen retention, and digestibility of crude fiber. This study used a completely randomized design experimental method (CRD) with five treatments, namely: treatment A (100\% Palm Oil), treatment B (90\% Palm Oil Waste + 10\% Rice Bran), treatment C (80\% Palm Oil Waste $+20 \%$ Rice Bran), treatment D (90\% Palm Waste $+10 \%$ Tofu Dregs) and treatment E (80\% Palm Oil Waste $+20 \%$ Tofu Dregs) with four replications. The experimental livestock used to measure nutritional quality, especially nitrogen retention and crude fiber digestibility, were 24 broilers CP 707 aged six weeks (average weight of 1,500 g/head). The variables observed were crude protein content, crude fiber, nitrogen retention, and digestibility of crude fiber. The results showed that the different substrate compositions had very significant effects $(P<0.01)$ on crude protein content, crude fiber, nitrogen retention, and crude fiber digestibility. From the results of this study, it can be concluded that palm oil waste $90 \%+10 \%$ tofu pulp is the optimal (efficient) treatment with a crude protein content of 22.77 $(\%$ BK), crude fiber 14, $03(\%$ DM), nitrogen retention of $55.09(\%$ DM) and crude fiber digestibility 54.02 $(\% D M)$.

Keywords: palm oil waste, Lentinus edodes, crude protein, crude fiber, nitrogen retention, crude fiber digestibility 


\section{PENDAHULUAN}

Biaya pakan merupakan modal terbesar dalam beternak dimana sekitar 60$70 \%$ modal berasal dari pakan sehingga biaya pakan menjadi penentu keberhasilan peternakan (Rasyaf, 2003). Ketersediaan pakan konvensional umumnya berfluktuatif karena perubahan iklim akan mempengaruhi produksi serta persaingan antar peternak dalam memperoleh bahan pakan menyebabkan harga bahan pakan cendrung akan lebih mahal. Salah satu upaya yang dapat dilakukan untuk menekan biaya ransum yaitu dengan cara pemanfaatan pakan non konvensional seperti limbah sawit yang merupakan limbah agroindustri kelapa sawit.

Pada tahun 2017 luas areal pekerbunan kelapa sawit diperkirakan sekitar 8.417.300 ha dengan produksi minyak 25.093.400 ton (Badan Pusat Statistik, 2018). Menurut Batubara et al. (2003) bahwa satu hektar kebun kelapa sawit menghasilkan 10-15 ton TBS (tandan buah sawit) segar. Dalam setiap hektar kebun sawit menghasilkan lumpur sawit 840-1.260 kg dan $567 \mathrm{~kg}$ bungkil inti sawit (Sianipar et al., 2003).

Lumpur sawit merupakan limbah yang dihasilkan dari proses pembuatan minyak kelapa sawit. Menurut Nuraini et al. (2016) kandungan nutrisi lumpur sawit berdasarkan bahan kering yaitu protein kasar $11,30 \%$, dan energi metabolisme $1.550 \mathrm{kkal} / \mathrm{kg}$, selanjutnya dijelaskan bahwa bungkil inti sawit memiliki kandungan nutrisi yaitu protein kasar 16,30\% dan energi metabolisme $2.020 \mathrm{kkal} / \mathrm{kg}$. Lumpur sawit dan bungkil inti sawit berpotensi digunakan sebagai pakan alternatif, tetapi didalam penggunaanya lumpur sawit hanya dapat diberikan sebanyak 5\% dalam ransum unggas, karena adanya faktor pembatas yaitu serat kasar sebesar 25,80\% (selulosa 20,22\%) dan lignin 19,19\% (Nuraini et al., 2016), mineral Cu 28,16 ppm (Gusri, 2020). Menurut Sinurat (2003) pemberian yang melebihi dari $5 \%$ dapat menurunkan konsumsi pakan dan pertumbuhan yang melambat.

Penggunaan bungkil inti sawit didalam ransum broiler hanya dapat diberikan sampai 10\% (Sinurat, 2012), hal ini disebabkan bungkil inti sawit memiliki kandungan serat kasar sebesar 20,75\% (selulosa 17,67\%) dan lignin 16,96\% (Nuraini et al., 2016), mengandung $\mathrm{Cu}$ (tembaga) 48,04 ppm (Mirnawati et al., 2008), dan mannan 35,2\% (Fan et al., 2014).

Campuran lumpur sawit dan bungkil inti sawit mengandung protein kasar 13,80\%, tetapi kandungan serat kasar masih tinggi yaitu $23,27 \%$ (selulosa 18,94\%, lignin 18,07\%) sehingga perlu dilakukan upaya untuk menurunkan serat kasar (terutama lignin dan selulosa) salah satunya difermentasi dengan Lentinus edodes. Lentinus edodes merupakan fungi pelapuk putih yang tumbuh baik pada media yang mengandung lignin dan selulosa tinggi (Denny et al., 2013). Enzim LiP, MnP, dan lakase merupakan enzim yang berperan dalam pemecahan lignin dan selulosa (serat kasar), dimana enzim ini dihasilkan oleh fungi pelapuk putih terutama Lentinus edodes (Samsuri et al., 2007). enzim protease (Fonseca, 2014), enzim selulase (Elisashvili et al., 2007).

Beberapa faktor yang harus diperhatikan untuk keberhasilan fermentasi media padat adalah dosis inokulum, lama fermentasi komposisi substrat dan ketebalan substrat (Nuraini, 2006). Substrat media fermentasi harus mengandung sumber karbon, nitrogen, vitamin dan mineral sebagai sumber nutrisi untuk mendukung pertumbuhan dan perkembangan Lentinus edodes (Nuraini et al., 2019).

Hasil-hasil penelitian fermentasi dengan Lentinus edodes menunjukkan bahwa komposisi substrat dengan penambahan ampas tahu ataupun dedak padi memberikan kandungan dan kualitas nutrisi substrat lebih tinggi dari yang tidak diberikan penambahan bahan lain. Menurut Nuraini et al. (2019) fermentasi dengan Lentinus edodes menunjukan bahwa campuran $80 \%$ bungkil inti sawit dengan $20 \%$ dedak padi merupakan komposisi terbaik yang dapat meningkatan protein kasar sebesar 35,40\% (dari 15,00\% 
menjadi $20,30 \%$ ) dan terjadi penurunan serat kasar sebesar 43,34\% (dari 20,9\% menjadi $14,58 \%$ ) dengan dosis inokulum $8 \%$ dan lama fermentasi 9 hari. Hal ini disebabkan komposisi substrat dengan penambahan dedak berkaitan dengan vitamin B1 dan sifat porositas dari dedak padi sehingga memberikan aerasi/ pergerakan udara yang lebih baik dalam substrat sehingga Lentinus edodes tumbuh lebih banyak. Kandungan nutrisi dedak padi adalah protein kasar 12,90\%, vitamin B1 dan berbagai mineral antara lain besi, aluminium, kalsium, fosfor, magnesium, mangan, dan seng (Astawan, 2010).

Komposisi substrat dengan penambahan ampas tahu fermentasi dengan Lentinus edodes diperoleh campuran $80 \%$ limbah buah nenas dan $20 \%$ ampas tahu merupakan komposisi substrat yang cocok dan diperoleh peningkatan protein kasar sebesar 96,76\% (dari 9,92\% menjadi 19,54\%) dan retensi nitrogen 55,83\% (Syafitri, 2019), diperoleh aktivitas enzim selulase 2,35 U/ml, penurunan serat kasar 45,33\% dan kecernaan serat kasar 54,23\% (Faiz, 2019). Ini berkaitan dengan ampas tahu mengandung protein kasar cukup tinggi yaitu $28,50 \%$ sebagai tambahan sumber nitrogen. Bagaimana komposisi substrat yang cocok untuk Lentinus edodes dalam meningkatkan kandungan dan kualitas nutrisi limbah sawit belum diketahui.

\section{METODE}

\section{Materi Penelitian}

Bahan baku yang digunakan dalam penelitian ini adalah lumpur sawit, bungkil inti sawit diperoleh di sekitaran Kabupaten Pasaman Barat, Provinsi Sumatera Barat. Jamur yang digunakan adalah Lentinus edodes yang diperoleh dari Laboratorium Mikrobiologi IPB Bogor dan diremajakan di Laboratorium Teknologi Industri Pakan Fakultas Peternakan, Universitas Andalas. Ternak percobaan yang digunakan untuk pengukuran kualitas nutrisi terutama retensi nitrogen dan kecernaan serat kasar adalah ayam broiler umur 6 minggu (berat rata-rata $1.500 \mathrm{gr} / \mathrm{ekor}$ ) sebanyak 24 ekor (N-endogenus 2 ekor dan kontrol 2 ekor). Peralatan yang digunakan pada penelitian ini adalah timbangan analitik, autoclave, oven, seperangkat peralatan untuk analisa proksimat dan kandang metabolik.

\section{Proses Fermentasi}

Pertama substrat disiapkan sesuai dengan variasi perlakuan, kemudian lakukan sterilisasi dengan autoclave pada suhu $121^{\circ} \mathrm{C}$ selama 15 menit, selanjutnya dibiarkan hingga suhu turun mencapai suhu kamar yaitu $25-30^{\circ} \mathrm{C}$. Setelah itu diinokulasikan Lentinus edodes sebanyak $8 \%$ dari jumlah substrat, kemudian diaduk hingga merata dan diratakan dengan ketebalan $1 \mathrm{~cm}$ dan diinkubasi selama 9 hari. Produk fermentasi tersebut ditimbang kembali berat segarnya dan dikeringkan pada oven suhu $80^{\circ} \mathrm{C}$ selama 2 jam untuk mematikan jamur. Langkah selanjutnya dilakukan pengeringan pada oven suhu $60^{\circ} \mathrm{C}$ selama 12 jam dan setelah itu dilakukan penggilingan sampai halus.

\section{Metode Penelitian}

Penelitian ini dilakukan dengan menggunakan metode eksperimen. Rancangan percobaan yang digunakan adalah Rancangan Acak Lengkap (RAL) 5 perlakuan dengan 4 kali ulangan.

Variasi perlakuan terdiri dari ;

$A=100 \%$ Limbah Sawit (50\% Lumpur Sawit $+50 \%$ Bungkil Inti Sawit)

B $=90 \%$ Limbah Sawit (45\% Lumpur Sawit $+45 \%$ Bungkil Inti Sawit $)+10 \%$ Dedak Padi

$\mathrm{C}=80 \%$ Limbah Sawit (40\% Lumpur Sawit $+40 \%$ Bungkil Inti Sawit $)+20 \%$ Dedak Padi

D $=90 \%$ Limbah Sawit (45\% Lumpur Sawit $+45 \%$ Bungkil Inti Sawit) + 10\% Ampas Tahu

$\mathrm{E}=80 \%$ Limbah Sawit (40\% Lumpur Sawit $+40 \%$ Bungkil Inti Sawit) $+20 \%$ Ampas Tahu

\section{Parameter yang diamati}


1. Kandungan protein kasar (\%) (AOAC, 1990)

2. Retensi Nitrogen (\%) (Sibbald, 1985)

3. Serat kasar (\%) (AOAC, 1990)

4. Kecernaan serat kasar (\%) (Sibbald, 1975)

Data penelitian yang diperoleh akan dianalisis statistik menggunakan analisis ragam sesuai Rancangan Acak Lengkap (RAL) 5 perlakuan dengan 4 ulangan. Perbedaan antar perlakuan diuji dengan Duncan's Multiple Range Test (DMRT).

\section{HASIL DAN PEMBAHASAN}

\section{Pengaruh Perlakuan terhadap Kandungan Protein Kasar}

Pengaruh komposisi substrat yang berbeda yang difermentasi dengan Lentinus edodes terhadap kandungan protein kasar (\%BK) dari limbah sawit dapat dilihat pada Tabel 1. Rataan kandungan protein kasar yang tertinggi terdapat pada perlakuan $\mathrm{D}$ dan E yaitu berturut-turut $23,77 \%$ dan $24,50 \%$, dan rataan kandungan protein kasar terendah terdapat pada perlakuan A yaitu 19,83\%.

Hasil analisis ragam menunjukkan bahwa limbah sawit dengan komposisi substrat berbeda yang difermentasi dengan Lentinus edodes memberikan pengaruh berbeda sangat nyata $(\mathrm{P}<0,01)$ terhadap kandungan protein kasar dari limbah sawit. Hasil uji DMRT menunjukkan bahwa kandungan protein kasar limbah sawit yang difermentasi dengan Lentinus edodes pada perlakuan D berbeda tidak nyata dengan perlakuan $\mathrm{E}$ tetapi sangat nyata $(\mathrm{P}<0,01)$ lebih tinggi dari perlakuan $\mathrm{A}$, $\mathrm{B}$ dan $\mathrm{C}$.

Tingginya kandungan protein kasar pada perlakuan D (90\% Limbah sawit $+20 \%$ ampas tahu) dan perlakuan E (80\% Limbah sawit $+20 \%$ ampas tahu) disebabkan oleh penambahan ampas tahu sebagai sumber nitrogen menyebabkan pertumbuhan Lentinus edodes subur pada substrat fermentasi karena ampas tahu mengandung protein kasar yang tinggi. Menurut Ningrum (2004) kandungan protein kasar ampas tahu yaitu 26,25\%. Pertumbuhan miselium yang subur pada substrat $90 \%$ Limbah sawit $+10 \%$ ampas tahu dan perlakuan $80 \%$ limbah sawit $+20 \%$ ampas tahu dipengaruhi oleh ketersediaan unsur $\mathrm{C}$ dan unsur $\mathrm{N}$ pada substrat yang cocok untuk pertumbuhan Lentinus edodes yaitu berturut-turut adalah 14:1 dan 13:1. Suburnya jamur menyebabkan sumbangan protein tubuh jamur kedalam substrat lebih banyak dari pada perlakuan lainnya. Dijelaskan oleh Musnandar (2003) jamur membutuhkan unsur kabon $(\mathrm{C})$ dan nitrogen $(\mathrm{N})$ sebagai sumber makanan atau nutrisi untuk metabolisme tubuh jamur. Fermentasi pod kakao dan ampas tahu (80:20) dengan Pleurotus ostreatus dapat meningkatkan protein kasar diperoleh

Tabel 1. Rataan protein kasar, retensi nitrogen, serat kasar dan kecernaan serat kasar (\%BK) fermentasi limbah sawit dengan Lentinus edodes pada komposisi substrat yang berbeda.

\begin{tabular}{lcccc}
\hline \multirow{2}{*}{ Perlakuan } & $\begin{array}{c}\text { Protein } \\
\text { Kasar }\end{array}$ & $\begin{array}{c}\text { Retensi } \\
\text { Nitrogen }\end{array}$ & $\begin{array}{c}\text { Serat } \\
\text { Kasar }\end{array}$ & $\begin{array}{c}\text { Kecernaan } \\
\text { Serat Kasar }\end{array}$ \\
\hline A (100\% Limbah Sawit) & $19,83^{\mathrm{c}}$ & $43,74^{\mathrm{c}}$ & $17,91^{\mathrm{a}}$ & $48,05^{\mathrm{d}}$ \\
B (90\% Limbah Sawit + 10\% Dedak Padi) & $20,60^{\mathrm{bc}}$ & $49,10^{\mathrm{c}}$ & $17,62^{\mathrm{a}}$ & $49,89^{\mathrm{cd}}$ \\
C (80\% Limbah Sawit + 20\% Dedak Padi) & $21,92^{\mathrm{b}}$ & $53,58^{\mathrm{b}}$ & $16,11^{\mathrm{b}}$ & $51,82^{\mathrm{bc}}$ \\
D (90\% Limbah Sawit + 10\% Ampas Tahu) & $23,77^{\mathrm{a}}$ & $55,09^{\mathrm{ab}}$ & $14,03^{\mathrm{c}}$ & $54,02^{\mathrm{ab}}$ \\
E (80\% Limbah Sawit + 20\% Ampas Tahu) & $24,50^{\mathrm{a}}$ & $56,13^{\mathrm{a}}$ & $13,49^{\mathrm{c}}$ & $56,08^{\mathrm{a}}$ \\
\hline SE & 0,49 & 0,77 & 0,33 & 0,84 \\
\hline
\end{tabular}

Keterangan: $*=$ Superskrip yang berbeda pada kolom yang sama berpengaruh berbeda sangat nyata $(\mathrm{P}<0,01) ; \mathrm{SE}=$ Standar error 
imbangan C:N = 12:1 (Purno, 2018).

Rendahnya kandungan protein kasar pada perlakuan A (100\% limbah sawit) mengakibatkan pertumbuhan miselium jamur kurang subur atau perkembangannya terhambat karena nitrogen yang digunakan untuk pertumbuhan jamur terbatas ketersediaannya didalam substrat fermentasi. Menurut Syafitri (2019) menyatakan bahwa fermentasi limbah buah nenas dengan Lentinus edodes tanpa menambahkan sumber $\mathrm{N}$ diperoleh peningkatan protein kasar paling rendah dari perlakuan lainnya dengan imbangan $\mathrm{C}$ : N yaitu 21,55:1.

Kandungan protein kasar terbaik pada penelitan ini yaitu pada perlakuan E (limbah sawit $80 \%+20 \%$ ampas tahu) sebesar $24,50 \%$. Hasil penelitian ini lebih tinggi dibandingkan dengan penelitian Damayanti (2018) fermentasi lumpur sawit dan dedak (80:20) dengan Phanerochaete chrysosporium dan Neurospora crassa diperoleh hasil kandungan protein kasar $24,24 \%$ dengan dosis $5 \%$ dan lama fermentasi 7 hari.

\section{Pengaruh Perlakuan Terhadap Kandungan Serat Kasar}

Pengaruh komposisi substrat yang berbeda yang difermentasi dengan Lentinus edodes terhadap kandungan serat kasar (\%BK) dari limbah sawit dapat dilihat pada tabel 1. Pada Tabel 1 dapat dilihat bahwa rataan kandungan serat kasar yang terendah terdapat pada perlakuan D dan E yaitu $13,49 \%$, dan rataan kandungan serat kasar tertinggi terdapat pada perlakuan A yaitu 17,91\%.

Hasil analisis ragam menunjukkan bahwa limbah sawit dengan komposisi substrat berbeda yang difermentasi dengan Lentinus edodes memberikan pengaruh berbeda sangat nyata $(\mathrm{P}<0,01)$ terhadap kandungan serat kasar dari limbah sawit. Hasil uji DMRT menunjukkan bahwa kandungan serat kasar limbah sawit yang difermentasi dengan Lentinus edodes pada perlakuan $\mathrm{E}$ sangat nyata $(\mathrm{P}<0.01)$ lebih rendah dari perlakuan $\mathrm{A}$, $\mathrm{B}, \mathrm{C}$ dan $\mathrm{D}$.

Rendahnya kandungan serat kasar pada perlakuan E (limbah sawit $80 \%+$ ampas tahu 20\%) dipengaruhi oleh aktivitas enzim selulase yang dihasilkan oleh jamur tersebut, semakin tinggi aktivitas enzim selulase yang dihasilkan maka kandungan serat kasar akan semakin rendah. Menurut Santos et al. (2012) menyatakan bahwa enzim selulase mampu merombak selulosa melalui proses katalis untuk melepaskan gula (glukosa). Ditambahkan oleh Datta and Chakravarty (2001) menyatakan bahwa perombakan selulosa menjadi glukosa merupakan kinerja beberapa enzim hidrolitik seperti enzim selulase yang menyebabkan serat kasar menjadi komponen yang lebih sederhana, pada analisa proksimat glukosa terhitung sebagai bahan ekstrak tanpa nitrogen (BETN).

Tingginya kandungan serat kasar pada perlakuan A disebabkan oleh rendahnya aktivitas enzim selulase akibat kurang suburnya pertumbuhan jamur dalam substrat fermentasi dengan rendahnya enzim selulase yang dihasilkan menyebabkan hanya sedikit selulosa yang dirombak sehingga penurunan serat kasarnya rendah.

Kandungan serat kasar terbaik pada penelitan ini yaitu pada perlakuan E (limbah sawit $80 \%+20 \%$ ampas tahu) sebesar $13,49 \%$. Hasil penelitian ini lebih tinggi dibandingkan dengan penelitian Maulana (2018) fermentasi lumpur sawit dan dedak (80:20) dengan Phanerochaete chrysosporium dan Neurospora crassa diperoleh hasil kandungan serat kasar 13,08\% dengan dosis 7\% dan lama fermentasi 9 hari.

\section{Pengaruh Perlakuan terhadap Retensi Nitrogen}

Pengaruh komposisi substrat yang berbeda yang difermentasi dengan Lentinus edodes terhadap retensi nitrogen $(\% \mathrm{BK})$ dari limbah sawit dapat dilihat pada Tabel 1. Rataan retensi nitrogen yang tertinggi terdapat pada perlakuan E yaitu 58,13\%, dan rataan retensi nitrogen terendah terdapat pada perlakuan A yaitu $43,74 \%$.

Hasil analisis ragam menunjukkan bahwa limbah sawit dengan komposisi substrat 
berbeda yang difermentasi dengan Lentinus edodes memberikan pengaruh berbeda sangat nyata $(\mathrm{P}<0,01)$ terhadap retensi nitrogen dari limbah sawit. Hasil uji DMRT menunjukkan bahwa retensi nitrogen limbah sawit yang difermentasi dengan Lentinus edodes pada perlakuan $\mathrm{E}$ berbeda sangat nyata $(\mathrm{P}<0.01)$ lebih tinggi dari perlakuan $\mathrm{A}$, perlakuan $\mathrm{B}$, dan perlakuan $\mathrm{C}$.

Tingginya retensi nitrogen pada perlakuan E (limbah sawit $80 \%+$ ampas tahu $20 \%$ ) yaitu $58,13 \%$ disebabkan kandungan protein meningkat pada bahan setelah fermentasi sehingga protein yang dikonsumsi ternak juga meningkat. Menurut Mc Donald et al. (1977) bahwa level protein yang diberikan dalam pakan akan mempengaruhi retensi nitrogen. Sefrinaldi (2013) menyatakan bahwa semakin tinggi kandungan protein yang dikonsumsi maka peluang protein yang tertinggal dalam tubuh semakin besar.

Rendahnya retensi nitrogen pada perlakuan A (100\% limbah sawit) yaitu: $43,74 \%$ disebabkan rendahnya kandungan protein kasar pada bahan setelah fermentasi, sehingga protein yang dikonsumsi ternak juga rendah, akibatnya nitrogen yang tertinggal dalam tubuh juga rendah. Menurut Corzo et al. (2005) bahwa nilai retensi nitrogen dipengaruhi oleh konsumsi dan kualitas protein. Ditambahkan oleh Mc Donald et al. (1977) bahwa level protein yang diberikan dalam pakan akan mempengaruhi retensi nitrogen.

Kandungan retensi nitrogen terbaik pada penelitan ini yaitu pada perlakuan E (limbah sawit 80\% + 20\% ampas tahu) sebesar $58,13 \%$. Hasil penelitian ini lebih tinggi dibandingkan dengan penelitian Nurhabiba (2019) fermentasi limbah sawit dan dedak (80:20) dengan Pleorotus ostreotus diperoleh hasil retensi nitrogen $54,76 \%$.

\section{Pengaruh Perlakuan terhadap Kecernaan Serat Kasar}

Pengaruh komposisi substrat yang berbeda yang difermentasi dengan Lentinus edodes terhadap kecernaan serat kasar (\%BK) dari limbah sawit dapat dilihat pada Tabel 1. Rataan kecernaan serat kasar yang tertinggi terdapat pada perlakuan E yaitu 56,08\%, dan rataan kecernaan serat kasar terendah terdapat pada perlakuan A yaitu 48,05\%. Hasil analisis ragam menunjukkan bahwa limbah sawit dengan komposisi substrat berbeda yang difermentasi dengan Lentinus edodes memberikan pengaruh berbeda sangat nyata $(\mathrm{P}<0,01)$ terhadap kecernaan serat kasar dari limbah sawit. Hasil uji DMRT menunjukkan bahwa kecernaan serat kasar limbah sawit yang difermentasi dengan Lentinus edodes pada perlakuan $\mathrm{E}$ berbeda tidak nyata dengan perlakuan $\mathrm{D}$ tetapi sangat nyata $(\mathrm{P}<0.01)$ lebih tinggi dari perlakuan $\mathrm{A}$, perlakuan $\mathrm{B}$, dan perlakuan $\mathrm{C}$.

Tingginya kecernaan serat kasar pada perlakuan E (limbah sawit 80\% + ampas tahu $20 \%$ ) dan D (limbah sawit 90\% + ampas tahu $10 \%$ ) yaitu berturut - turut adalah $56,08 \%$ dan $54,02 \%$ karena rendahnya kandungan serat kasar bahan setelah fermentasi sehingga meningkatkan kecernaan serat kasar. Menurut Julianto (2019) kecernaan serat kasar yang tinggi juga dapat dipengaruhi oleh proses fermentasi karena telah terjadi peregangan ikatan serat kasar sehingga memudahkan ternak dalam mencernanya. Ditambahkan oleh Tillman et al. (2005) serat kasar pakan menjadi faktor yang mempengaruhi daya cerna serat kasar. Rendahnya kandungan serat kasar bahan pakan berbanding terbalik dengan daya cerna serat (Wahju, 2004). Lentinus edodes memiliki sifat lingo-selulitik dan lingo-hemiselulitik yang mampu memecahkan ikatan lignin-selulosa dan lignin-hemiselulosa sehingga meningkatkan kecernaan serat kasar (Nuraini et al., 2019).

Rendahnya kecernaan serat kasar pada perlakuan A (100\% limbah sawit) disebabkan oleh tinggi kandungan serat kasarnya, sehingga sulit untuk dimanfaatkan oleh ternak. Kecernaan serat dipengaruhi oleh serat kasar (Despal, 2000). Ternak unggas atau hewan monogastrik hanya mampu memanfaatkan serat kasar sedikit, penggunaan nutrisi lainnya akan terganggu jika serat 
kasar tinggi dalam pakan (Wahju, 2004). Tingginya serat kasar dapat mengakibatkan terganggunya pencernaan zat-zat lainnya, mengakibatkan tingkat kecernaan menurun (Wahju, 2004). Tingginya serat kasar dapat mengakibatkan terganggunya pencernaan zatzat lainnya, mengakibatkan tingkat kecernaan menurun (Wahju, 2004). Serat kasar (selulosa, hemiselulosa dan lignin) hanya sebagai penganjal (pengenyang) yang kemungkinan besar sukar dicerna (Wahju, 2004).

Kecernaan serat kasar terbaik dan efisien pada penelitan ini yaitu pada perlakuan D (limbah sawit 90\% + 10\% ampas tahu) sebesar 54,08\%. Hasil penelitian ini lebih tinggi dibandingkan dengan penelitian Maulana (2018) fermentasi limbah sawit dan dedak (80:20) dengan Phanerochaete chrysosporium dan Neurospora crassa diperoleh kecernaan serat kasar 54,33\% dengan dosis $7 \%$ dan lama fermentasi 9 hari.

\section{DAFTAR PUSTAKA}

AOAC. 1990. Official Method of Analysis. Association of Official Analytical Chemists. Maryland.

Astawan, M. 2010. Potensi Dedak dan Bekatul Beras sebagai Ingredient Pangan dan Produk Pangan Fungsional. Gramedia Pustaka Utama, Jakarta.

Badan Pusat Statistik. 2018. Statistik Indonesia 2018. BPS Statistik Indonesia.

Batubara, L. P., K. Ginting, J. Simanhuruk, Sianipar, dan A. Tarigan. 2003. Pemanfaatan limbah dan hasil ikutan perkebunan kelapa sawit sebagai ransum kambing potong. Prosiding Seminar Nasional: Teknologi Peternakan dan Veteriner. Bogor. Hlm. $106-109$.

Corzo, A., C. A. Fritts, M. T. Kidd, and B. J. Kerr. 2005. Response of broiler chicks to essensial and non essensial amino acid suplementation of low crude protein diet. Animal Feed Science Technology 118: 319-327.
Damayanti, D. 2018. Pengaruh dosis inokulum dan lama fermentasi dengan Phanerochaete chrysosporium dan Neurospora crassa terhadap kandungan bahan kering, protein kasar dan retensi nitrogen dari campuran lumpur dan bungkil inti sawit. Skripsi. Fakultas Peternakan. Universitas Andalas, Padang.

Datta S. and D. K. Chakravarty. 2001. Comparative utilization of lignocellulosic components of paddy straw by Trichoderma lobyense and Volvariella volvacea. Indian J. Agric. Sci. 71:258-260.

Denny, Irawaty, dan G. Sutapa. 2013. Pengaruh jenis kayu terhadap pertumbuhan dua jenis jamur sebagai praperlakuan pada pemanfaatannya untuk energi. Fakultas Kehutanan. Universitas Gadjah Mada. Yogyakarta.

Despal. 2000. Kemampuan komposisi kimia dan kecernaan in vitro dalam mengestimasi kecernaan in vivo. Media Peternakan. 23 (3): 84 - 88.

Elisashvili, V., M.Penninckx., E. Kachlishvili., N.Tsiklauri., E. Metreveli., T., Kharziani., and G. Kvesitadze. 2007. Lentinus edodes and Pleurotus species lignocellulolytic enzymes activity in submerged and solid-state fermentation of lignocellulosic wastes of different composition. Bioresource Technology: 457-462.

Faiz, A. 2019. Pengaruh komposisi substrat yang berbeda difermentasi dengan Lentinus edodes terhadap aktivitas enzim selulase, penurunan serat kasar dan kecernaan serat kasar limbah buah nanas. Skripsi. Fakultas Peternakan. Universitas Andalas, Padang.

Fan, S. P., C. H. Chia, Z. Fang, S. Zakaria, and K. L. Chee. 2014. Deproteinated palm kernel cake-derived oligosaccharides: A preliminary study. AIP Conf Proc 1614. 2014: 61-64.

Fonseca, S. C. 2014. Modelling the 
influence of time and temperature on there spiration rate of fresh oyster mushrooms. Juornal Food Science and Technology International, 21: 593-603.

Gusri, R. 2020. Pemanfaatan campuran limbah sawit dan dedak padi yang difermentasi dengan Pleurotus ostreatus dalam ransum terhadap peforma dan kualitas telur puyuh. Tesis. Fakultas Peternakan. Universitas Andalas, Padang.

Julianto, D. 2019. Pengaruh penambahan sumber nitrogen yang berbeda pada pod kakao yang difermentasi dengan Pleurotus ostreatus terhadap aktivitas enzim selulase, serat kasar dan kecernaan serat kasar. Skripsi. Fakultas Peternakan, Universitas Andalas.

Lubis, D. A. 1963. Ilmu Makanan Ternak. Cetakan ke-2.PT Pembangunan Djakarta. Jakata.

Maulana, F. 2018. Pengaruh dosis inokulum dan lama fermentasi dengan Phanerochaete chrysosporium dan Neurospora crassa terhadap aktivitas enzim selulase, kandungan serat kasar dan kecernaan serat kasar dari campuran lumpur dan bungkil inti sawit. Skripsi. Fakultas Peternakan. Universitas Andalas. Padang.

Mc Donald, P. R. A., Edwards, and J. F. H. Greenhalgh. 1977. Animal Nutrition. Fourth edition. Longman, Hongkong.

Mc Donald, P., R.A. Edwards, J.F.D. Greenhalgh, C.A. Morgan, L.A. Sinclair, and R.G. Wilkinson. 2010. Animal Nutrition. 7th Ed. Prentice Hall, Pearson, Harlow, England, London, New York, Boston, San Fransisco, Toronto, Sydney, Tokyo, Singapore, Hong Kong, Seoul, Taipei, New Delhi, Cape Town, Madrid, Mexico City, Amsterdam, Munich, Paris, Milan.

Mirnawati, I. P. Kompiang, and Harnentis. 2008. Theroleof humic acid as heavy metal scavenger inprocessing palm kernel cake for poultry feed. Competitive Grant Research Report.
Ministry of Education and Culture, Indonesia.

Musnandar, E. 2003. Reput hayati sabut kelapa sawit oleh jamur Marasmius dan implikasi terhadap performan kambing. Disertasi. Universitas Padjadjaran, Bandung.

Ningrum. 2004. Pengaruh dosis inokulum dan lama inkubasi dari produk campuran ampas sagu dan ampas tahu fermentasi dengan Neurospora crassa terhadap kandungan BETN dan aktivitas enzim amylase. Skripsi Fakultas Peternakan Universitas Andalas. Padang.

Nuraini. 2006. Potensi kapang Neurospora crassa dalam memproduksi pakan kaya $\beta$-karoten dan pengaruhnya terhadap ayam pedaging dan petelur. Disertasi. Program Pasca Sarjana Universitas Andalas, Padang.

Nuraini., A. Djulardi, dan A. Trisna. 2016. Peningkatan kualitas lumpur sawit dan bungkil inti sawit dengan fungi ligninolitik, selulolitik dan karatenogenik untuk memproduksi daging dan telur rendah kolesterol. Laporan Kluster Guru Besar. Lembaga Penelitian Pengabdian Masyarakat. Universitas Andalas. Padang.

Nuraini, A. Djulardi, dan D. Yuzaria. 2019. Limbah Sawit Fermentasi Untuk Unggas. Suka Bina Press. ISBN: 978623-7018-31-5.

Nurhabiba. 2019. Pengaruh dosis inokulum dan lama fermentasi Pleurotus ostreatus terhadap bahan kering, protein kasar dan retensi nitrogen dari campuran limbah sawit dan dedak. Skripsi. Fakultas Peternakan. Universitas Andalas, Padang.

Purno, P. 2018. Pengaruh penambahan sumber nitrogen yang berbeda pada pod kakao yang difermentasi dengan Pleurotus ostreatus terhadap kandungan bahan kering, protein kasar dan retensi nitrogen. Skripsi. Fakultas Peternakan Universitas Andalas. 
Rasyaf, M. 2003. Beternak Ayam Pedaging. Panebar Swadaya. Jakarta.

Samsuri, M, M. Gozam, R.Mardias,M. Baiquni, H. hermansyah, A. Wijarnarko, B. Prasetya, dan M. Nasikin. 2007. Pemanfaatan selulosa bagas untuk produksi ethanol melalui sakarifikasi dan fermentasi serentak dengan enzim xylanase.

Santos, T. C. Gomes, D. P. P., Bonomo, R. C. F., and Franco, M. 2012. Optimisation of solid state fermentation of potato peel for the production of cellulolytic enzyme. Food Chemistry. 133: 12991304.

Sefrinaldi. 2013. Pengaruh dosis inokulum dan lama fermentasi dengan Phanerocaete chrysosphorium terhadap kandungan bahan kering, protein kasar dan retensi nitrogen campuran umbi ubi kayu dan ampas tahu fermentasi. Skripsi. Fakultas Peternakan. Universitas Andalas, Padang.

Sianapar, J., L. P. Batubara, S. P. Ginting, K. Simanihuruk, dan A. Tarigan. 2003. Analisis potensi ekonomi limbah dan hasil ikutan perkebunan kelapa sawit sebagai pakan kambing potong. Laporan Hasil Penelitian. Loka Penelitian Kambing Potong Sungai Putih. Sumatera Utara.
Sibbald, I. R. 1975. The effect of level intaken on metabolzable energy value measured with adult rooster. Poultry Sciences, 54: 1990-1998.

Sibbald, I. R. and Wolynetz, M. S. 1985. Estimates of retained nitrogen used to correct estimates of bioavailable energy. Poultry Sci., 64: 1506-1513.

Sinurat, A. P. 2003. Pemanfaatan lumpur sawit untuk bahan pakan unggas. Jurnal Wartazoa. 13(2): 39- 47.

Sinurat, A. P. 2012. Teknologi pemanfaatan hasil samping industri sawit untuk meningkatkan ketersediaan bahan pakan unggas nasional. Puslitbangnak. Bogor.

Syafitri, R. 2019. Pengaruh komposisi substrat yang berbeda pada limbah buah nenas yang difermentasi dengan Lentinus edodes terhadap kandungan bahan kering, protein kasar dan retensi nitrogen. Skripsi. Fakultas Peternakan. Universitas Andalas. Padang.

Tillman, A. D, H. Hartadi, S. Reksohadiprodjo, S. Prawirokusumo, dan S. Lebdosoekojo. 2005. Ilmu Makanan Ternak Dasar. Gadjah Mada University Press, Yogyakarta.

Wahju, J. 2004. Ilmu Nutrisi Unggas. Gadjah Mada University Press, Yogyakarta. 